\title{
CURSO INTENSIVO DE PROCESSO CIVIL
}

O Prof. Adolfo Gelsi Bidart, catedrático da Faculdade de Direito e Ciências Sociais da Universidade da República Oriental do Uruguai, realizou um Curso Intensivo de Processo Civil, a convite do Departamento de Direito Civil e Processual Civil, da Faculdade de Direito da Universidade Federal do Paraná, no período de 23 a 27 de outubro de 1978.

Participaram dos estudos desenvolvidos pelo mestre uruguaio inúmeros estudantes, advogados, juízes e membros do Ministério Público, destacando-se também a presença de alguns desembargadores do Tribunal de Justiça e do Tribunal de Alçada do Estado, afora professores do nosso principal estabelecimento de ensino jurídico.

O Curso do Prof. Bidart atingiu plenamente os seus objetivos, através de cinco palestras sobre os seguintes temas processuais:

1

Processo e realidade (pressuposto do processo. Incidência durante o processo. O problema da execução. A decisão e a realidade futura).,

II

Processo e sugeitos (os sugeitos principais e os complementares. Juiz e Árbitro. As partes principais. Os terceiros. Os funcionários judiciais. Humanização do processo).

III

Processo, estrutura e tempo (o processo como estrutura jurídica; peculiaridades. O tempo "exterior" ao processo. O tempo no processo. O tempo "atual" - a época e o processo).

IV

Processo e validade jurídica (validade e nulidade em relação ao processo. O processo "al revés", segundo a nulidade. Elementos da nulidade. Princípios. Vias processuais para o tratamento da nulidade). 


\section{V}

Processo e valores jurídicos (Ordem. Segurança. Liberdade. Justiça. Paz. Fraternidade).

Foram expedidos certificados de aproveitamento e freqüência aos inscritos.

\section{Encerramento do Curso}

As palestras foram desenvolvidas no Salão Nobre da Faculdade de Direito, no Edifício do Setor de Ciências Sociais Aplicadas, com a presença, dentre outros, dos professores Othelo Werneck Lopes, diretor do Setor e Ary Florêncio Guimarães, chefe do Departamento de Direito Civil e Processual Civil, do Curso de Direito da UFPr..

No dia 27 de outubro, finda a última palestra do Prof. Bidart, os estudantes de direito que lotavam as dependências do auditório, com a diretoria do Centro Acadêmico HUGO SIMAS à frente prestigiando o evento cultural, prestaram significativa homenagem de apreço e reconhecimento ao mestre da terra de Couture, ofertando-lhe, numa manifestação espontânea e de alto sentido universitário, uma placa de prata, tendo usado da palavra, na ocasião, o aluno Eduardo Alberto Virmond, que produziu de improviso delicada e expressiva oração, em que exaltou os méritos jurídicos e humanísticos do conferencista.

Em seguida, o Prof. Adolfo Gelsi Bidart, agradecendo a manifestação estudantil e a acolhida que tivera em Curitiba, pronunciou as seguintes palavras de encerramento do seu proveitoso Curso e calorosamente aplaudidas no seu final:

"I - El agradecimiento sólo puede ser de quien tuvo a su cargo el desarrollo del curso.

A todos los brasileños de Curitiba, simbolizados en el Director del Instituto de Derecho Civil y Derecho Procesal Civil, prof. Ary Florencio Guimarãas. Ante todo, por haber-me permitido, nuevamente. estar en presencia de amigos, como Guimaraes, Moniz de Aragao, Athos Velloso y tantos otros.

Em segundo lugar, por haber podido dedicar, con intensidad, unos días, a pensar juntos, ante y con tal calificada concurrencia, en problemas esenciales del proceso que importan a la vida de los hombres de hoy.

Por otro lado, por haber permitido la realización, - en la tierra amiga y querida del Brasil, con la acogida tan generosa y fraternal 
de sus hijos, - de una tarea, fundamental en mi vida, como es la enseñanza.

II - No puedo menos de llegar con emoción, a este momento en que termina el curso, tal vez por aqu-llo que dice John Godey: "a su edad y a la mía, toda terminación es una pequeña muerte" ("Talisman", ed. Emecé, p. 290) y porque en la vida, todo distanciamiento de personas que uno quiere, provoca una rupiura que resulta difícil, cada vez más, superar.

III - Los estudiantes, que con tanta atención que me honra han asistido a este curso, me disculparán si, como viejo profesor, quiero dirigirles una palabra que apunta, más que a la información científica, a la formación personal, que sigue siendo la finalidad básica y esencial de la enseñanza, comc parte de la educación.

Ante las dificultades del mundo actual, ante el agobio de los problemas que nos golpean por la misma unificación del planeta, quisiera recordarles que debemos hacer un eesfuerzo por conservar la esperanza.

Un gran físico contemporáneo, uno de los padres de la Física atómica - Max Born - dice que "En la vida en común de los hombres... la esperanza es una fuerza movilizadora". Pero "solamente si tenemos alguna esperanza, actuamos de tal forma que pueda cumplirse (realizarse) tal esperanza" ("La responsabilidad del científico", ed. Labor, p. 145). Vale decir, que la esperanza, para que pueda incorporarse a nuestra vida y transformarla, requiere, también, un gran esfuerzo de actividad por nuestra parte.

Este esfuerzo habrá de llevarse a cabo en el sentido que señalaba Pablo de Tarsos: "mientras tenemos tiempo, hagamos en bien a todos" (Gálatas, 6, 10).

Allí está la finalidad y el programa, que no esmeramente genérico, sino que se realiza de manera concreta, para esa transformación del mundo que siempre se nos predica y que tantas veces se pretende efectuar mdiante utópicas y también crueles actividades.

Ayer, como hoy y como siempre, hacer el bien que cada hombre necesita y que cada uno de nosotros pueda realizar.

Como estudiantes, como profesores, como hombres, alli sigue el norte, para un mundo mejor". 